\title{
Hegemony and Regionalism: Brazil's Subordination of Argentina through the Formation of Mercosur
}

\author{
Aditya Pratama \\ Undergraduate Student of International Relations Department at Universitas Lampung \\ aditya.pratama1505@students.unila.ac.id
}

\begin{abstract}
Rivalitas strategis antara Brazil dan Argentina di masa Perang Dingin membuat kawasan Amerika Latin relatif tidak kohesif dan tidak terintegrasi. Ketidakbersatuan ini dimanfaatkan oleh Amerika Serikat (AS) dalam rangka mengimplementasikan doktrin Monroe-nya di mana AS perlu fokus atas situasi di Amerika Latin. Sehingga AS pada masa itu dapat membangun hegemoninya di kawasan tersebut misalnya dengan adanya otoritas moral AS atas junta-junta militer di Brazil, Argentina, dan Bolivia. Namun demikian, pasca Perang Dingin AS disibukkan dengan situasi di Timur-Tengah dan Indo-Pasifik, oleh sebab itu prioritasnya terhadap Amerika Latin relatif berkurang. Peristiwa ini dimanfaatkan oleh Brazil dalam rangka mengaktualisasikan keinginannya menjadi kekuatan regional di kawasan tersebut melalui pendirian Mercosur dan memarginalkan kekuatan regional berpotensi lainnya seperti Meksiko dari sebuah kawasan baru yang bernama Amerika Selatan. Penelitian ini berpendapat bahwa tujuan Brazil dibalik pendirian Mercosur adalah tidak hanya untuk kepentingan ekonomi tetapi juga guna menenangkan Argentina dan memasukkan Argentina ke dalam hegemoninya. Dengan menggunakan metode kualitatif, tulisan ini menganalisis upaya-upaya Brazil melalui perspektif sub-sistem regional di mana harus terdapat sebuah pemimpin kawasan dalam proses membangun suatu kawasan baru.
\end{abstract}

Kata Kunci: Brazil, Argentina, hegemoni, regionalisasi, sus-sistem regional, Mercosur

\section{Introduction}

Perhaps globalisation is inevitable in the contemporary world. Even, an academic maintains, that regionalisation is the highest level in the development of world politics, 
whereas globalisation occurs before regionalisation ${ }^{1}$. The rise of regionalisation has invited a variety of new researches which is analysed from a number of perspectives and themes. The themes of researches ranging from old regionalism, new regionalism, regionalisation, and inter-regionalism. Yet, regionalism has been a leading object in international relations research.

A number of scholars have studied regionalism and hegemony ${ }^{2}$, their researches centre on hegemonic actor and its role in economic development in regions, the capacity of outer regional institution in resulting a regionalisation in other region, and regionalisation and great powers' rivalry. However, a few of researches have been undertaken which analyse the connection between regionalisation and the ambition of regional state to become a regional power or regional leader through the foundation of regional organisation. This research aims to fill this gap by examining the Brazil's regional power inclination in South America. In particular, this paper focuses on Brazil's regional ambition through the creation of Mercosur.

The creation of the Treaty of Asuncion by Paraguay ${ }^{3}$, Uruguay, Brazil, and Argentina on 26 March 1991 marked the installation of Mercosur. The organisation has several objectives related with economic integration, specifically increasing market liberalisation, accelerating economic development, enhancing infrastructure and coordination amongst its members, managing virtuously resources in South America, protecting the environment, and cooperating in industrial and macroeconomic direction. ${ }^{4}$ Nonetheless, if such organisation is appraised cautiously, there is a predeterminant that must be explored more precisely, i.e. Brazil and regional power ambition and its subordination of Argentina through this organisation. Scholarly papers which have been examined yet sporadic. Thus, in this respect the paper will be assessing the relationship between Mercosur and Brazil's ambition to become a regional hegemon. This paper will be organised into several discussions, theoretical approaches, Brazil and Argentina strategic rivalry and rapprochement, the origin of Mercosur, as well as analysis of Brazil, Argentina, and Mercosur.

\footnotetext{
${ }^{1}$ Peter Dicken. 2015. Global Shift: Mapping the Changing Contours of the World Economy. 7th. New York: The Guilford Press, 8.

${ }^{2}$ See Jennifer Pédussel Wu. 2009. "Successful" Regionalism and the Role of Regional Hegemons. Working Paper, Berlin: Berlin School of Economics and Law., Beeson, Mark. 2014. "American Hegemony and Regionalism: The Rise of East Asia and the End of the Asia-Pacific." Geopolitics 11 (4): 541-550. doi:10.1080/14650040600890727.

${ }^{3}$ The Treaty was amended once, and it has additional treaty that is the Protocol of Ouro Preto that centred on institutional issues and dispute settlement.

${ }^{4}$ 2016. About Mercosur. Accessed October 24, 2018. http://en.mercopress.com/about-mercosur.
} 


\section{Theoretical Approaches}

This paper operates some theoretical approaches regarding reconcilement in South America namely regional sub-system, regionalisation, and hegemonic theory.

Subsystem approach emerges as a critique to international system analysis, in which it solely analyses great powers' interactions while uncommitted states or small powers are rather ignored in that analysis. ${ }^{5}$ International system, which is intended to provide a complete analysis in international system, has also failed to explain relationship conditions in smaller regions. System approach is criticised for being too abstract and constant which it does not explain the role of actors in the system, oversimplifies the reality in world politics, and it is unable to explicate transformation within the system. As Buzan argued that within the system there are different systems, hence to comprehend the entire system, other parts of system must be tested. ${ }^{6}$ On the other hand, subsystem approach is aimed to complement analyses in area studies which has relatively different level of analysis. Moreover, international system approach does not represent the reality in a regional system, for example mutual deterrence between two superpowers in the Cold War era was not a significant problem for smaller states, since these countries had had its own problem that must be examined by different approach. ${ }^{7}$

Regional subsystem is defined by McClelland as a structure which it has its own interaction patterns and distinctive boundary from larger environment and it is also recognised by other powers. ${ }^{8}$ Then, regional sub-system approach is comprehensively studied by William Thompson, he lists components of regional sub-system by reviewing other scholars' writing on international and regional sub-system. Thompson maintains that regional sub-system is a smaller system which it has its own systemic properties. According

\footnotetext{
${ }^{5}$ Leonard Binder .1958. "The Middle East as a Subordinate International System." World Politics 10 (03): 408429., 411

${ }^{6}$ Haluk Özdemir .2015. “An Inter-Subsytemic Approach in International Relations.” All Azimuth 4 (1): 5-26.

${ }^{7}$ Leonard Binder. Op.cit., 409.

${ }^{8}$ Charles A. Mcclelland. 1996. Theory and the International System. New York: Macmillan. in Thompson, William R. 1973. "The Regional Subsystem: A Conceptual Explication and a Propositional Inventory." International Studies Quarterly 17 (1): 89-117., 96.
} 
to Thompson, there are some pre-requirements and components of regional subsystem that significantly contribute in distinguishing a regional subsystem from international one. Those elements are, (1) geographical proximity, (2) the pattern of relations amongst countries are regular and intense, (3) intra-relatedness in which there is a systemic influence from one state to another state, (4) internal and external acceptances, (5) there exist more than one actor, (6) actors are secondary powers, (7) change in the dominant system will shake the smaller system and change in the inferior system will insignificantly affect the dominant system, (8) some stage of ethnic, cultural, linguistic, social linkages amongst states in the region, (9) a relatively integrated region, (10) there exist a regional institution, self-reliance of the system over the bigger system, and (11) common developmental status. ${ }^{9}$

The second approach is power transition theory (PTT), which also emerges due to the preoccupation of realism with balance of power theory. According to Organski who is a pathbreaker of PTT theory, balance of power does not produce a power equilibrium as advocated by its proponents. The power of the state constantly change that it might be not just to balance against the opponent, but also it wants to change the current international order because it is perhaps dissatisfied with the status quo state. He argues that non-status quo states can be challenging for great powers, since small states have built a significant industry and political stability that can be employed to dispute the status quo states. More specifically, those elements of national power are population size, political efficiency, and economic development. When the components maturate tremendously, those can induce unstableness in international system. ${ }^{10}$ Whether the new contender will be victorious or not, the status quo state will always be facing a new emerging power.

State, which is potential to be a rising or emerging power can be checked through its development from a potential power to mature power. Specifically, Organski divides at least there are three stages of power transition, namely potential power, transitional growth in power, and power maturity phases. First, the stage of potential power, in this stage a state is yet in agricultural phase. Economic performance and standards of living are comparably low than great powers. The state is still ruled by feudal and aristocrat groups, hence public participation in political process is relatively low. Moreover, government's agencies such as bureaucracy, police, and army are not advanced yet. Second, the power transition phase, in

\footnotetext{
${ }^{9}$ William R. Thompson. 1973. "The Regional Subsystem: A Conceptual Explication and a Propositional Inventory." International Studies Quarterly 17 (1): 89-117., 93.

${ }^{10}$ A.F.K. Organski. 1968. World Politics. 2nd. New York: Random House, 338.
} 
this level the state has conversed from a rural phase to an industrial stage. The people of the nation are being more conscious of what government's policy. Third, is the stage of advancement, the state has reached its maturity ranging from its bureaucracy, economic, cultural, social, and economic aspects. ${ }^{11}$ Countries that have achieved the third stage are dominated by Western and some East Asia countries, such as Japan, South Korea, and gradually China.

The potential of power transition can be explained through three distinct periods which the age of pre-industrial society, industrial revolutions, and the third period, which will occur in the future. First, the pre-industrial period happens when there is no any state that is able to attain modernisation in any aspect. Thus, every state in this period has relative similar level in terms of development. Second, industrial revolutions period, in this era there are some advanced states that have an accomplished industry, military, and educated people which can be a potential power for the state to become a hegemon. Third, a period that, according to Organski will be encountered in the future, any state has been an advanced nation, thus the potential of change in an international order is much bigger than the previous periods.

Nevertheless, the intention of states to become a new status quo state is not always the same. Strictly speaking, states that would be a new hegemon can be separated into four categories. ${ }^{12}$ First, powerful but satisfied states, the states have been advanced as a dominant state, however those states accept the prevailing international order in the interest of protecting its economy and other interests from any kind of retaliation from the status quo state. States that can be categorised into this classification, for example, Japan and Germany, as well as western countries, such as the United Kingdom, France, and potentially Canada. In spite of protecting their interests, the states recognise to alter the prevalent international order is not as untroublesome as previous era. For example, states such as Japan and Germany cannot realise their ambition anymore as pre-World War II, because their militaries have been dismantled by the Allies, their relationship with the status quo state has been increasingly closer than before, and public opinion regarding the military is hostile.

The second category is powerful and but dissatisfied states. These states emerge when the allocation of wealth in international order is not even. The dissatisfied states do not obtain the wealth as they want because the status quo state is not willing to share its domination over the

\footnotetext{
${ }^{11}$ Ibid, 339-344.

${ }^{12} \mathrm{Ibid}, 374$.
} 
privilege. ${ }^{13}$ For example because of economic and political consideration the Soviet Union had challenged the liberal international order dominated by the United States.

The third category is weak and satisfied states. Those states are lacking particularly in terms of military and population. States such as Norway, Sweden, Denmark, Finland, South Korea Poland, Czech Republic, Austria, Liberia, Ghana, and Cote d'Ivoire can be classified into this class. These countries consent the current international order as a result of their powerlessness to object the status quo state. Furthermore, it might be since they receipt a substantial amount of wealth that is provided by opportunities in the present international order. $^{14}$

States such as Venezuela, Cuba, Bolivia, are the last group of states that are weak but dissatisfied with the current international order. Perhaps as the above-mentioned that their potential to alter the international order is scant unless if those states along with new discontent states unitedly dissent contra the status quo state, it potentially will harm the international order but not eventually shall devastate the hegemonic state. For illustration, Cuba with assistance from the Soviet Union was confronting the United States through the deployment of missiles in the Cuban terrain, this tragedy nearly provoked a nuclear war between the two superpowers (the US and the Soviet Union). Nevertheless, the calamity did not completely alter the international order or annihilate the United States.

There are several factors why the state wants to stand up to a status quo state. According to John Mearsheimer that anarchic system in international politics is stimulating the state to quest for power. Such an argumentation emerges from his main thesis which cites Morgenthau's postulate animus dominandi or state's boundless effort for seeking the power. The exploration of power is not grounded on the human nature as argued by Thomas Hobbes, instead he argues the state persistently quests for power since the state necessitates security. Thus, on this matter Mearsheimer differs from Morgenthau' classical realism. Though Mearsheimer is a part of structural realism group, however he deviates from Waltz' neorealism version. He disaccords with Waltz's argument that the state will terminate its pursuance of power ${ }^{15}$, rather he argues any state shall not halt in questing for power. Why the state is perpetually appetite for power, as written by Mearsheimer that power does matter

\footnotetext{
${ }^{13}$ Ibid, 364-66.

${ }^{14}$ Ibid, 367-68.

${ }^{15}$ Waltz argues that the state just wants to maintain its position in the system, or the state is satisfied with current situation as long as it is not invaded by other actors.
} 
given to its decisive role in preserving the state's survival. ${ }^{16}$ Yet, a superpower shall not accept the power that has been attainted unless chances for increment of power is limited.

On the issue of hegemony, Mearsheimer states that a status quo state is non-existent, since as he argues, each state is seeking for power which sacrifices the interest of adversaries. Moreover, the costs of aspiration to be a hegemon outperform the benefit when hegemony is not yet achieved by the state. ${ }^{17}$ Even Mearsheimer' offensive realism does not recognise a global hegemony in the anarchic system unless the state is monopolising nuclear weapons in the system in which the state is not concerned of antagonists' revenge. He unwaveringly believes that a hegemon only exists in a regional level in which there is no any country that is capable to counterweight the hegemon. Whereas in a larger system (international level) there are more than one great power, hence it is inconceivable if there are two or more hegemons in international system.

Even if in the system does not have any aggressive country, protecting measure is yet considered by the state which it can harm or threaten other states, because the anarchic system stimulates vulnerability, miscalculation, misperception, and uncertainty that need a protecting measure to avoid those. Yet, defending measure can be perceived as an aggression by other countries. Thus, in this regard war cannot be forestalled by the state except when deterrence is successfully conducted by the adversaries.

\section{Brazil-Argentina Strategic Rivalry and Rapprochement}

As the two largest states in South America, analysis of the rivalry of the two states is crucial in this paper. Only in 1980, the two states were able to improve their diplomatic relations after endless violent peace (strategic tension) and some failed summits in 1947, 1961, and 1972. There are some factors why the rapprochement between the two states failed before 1980. First, from parochial perspective, bureaucratic obstacles were the most profound ranging from foreign ministries, militaries, and domestic political rivals. Second, realist argues, that an anarchic international system boosted the rivalry between the two states which, in order to ensure their own national security, the two states had to be cognisant of each other. In the anarchic international system no one can provide security unless by states themselves.

\footnotetext{
${ }^{16}$ Glenn H. Snyder. 2002. "Mearsheimer's World-Offensive Realism and the Struggle for Security: A Review Essay." International Security 27 (1): 149-173., 151-52.

${ }^{17}$ For example, the invasion of other territory does not compensate that state economically and strategically.
} 
Moreover, according to Stephen Walt that proximity determines the relative threat from one state to another state. Whereas the success of the two countries' rapprochement from constructivist perspective is that the two states had had their own initiatives to improve relations, in other words there was no any external factor which influenced and stimulated the advancement of the two countries' relations. Second, liberal argues that democratic peace theory that advanced the relationship of the two states from strategic rivalry to cordial relationship. Third, realist maintains common enemy such as insurgent groups made the two states commenced taking their relationship from violent peace to rapprochement phase. Fourth, parochial perspective proposes alternative view in which Brazil and Argentina considered enhancing diplomatic relations as the consequence of oil crisis in the 1970s. To verify these arguments, I shall analyse the dynamic of the two states relationship from independence period two 1980s.

Brazil and Argentina gained independence respectively on September 7, 1822 and July 9, 1816. The two countries have had endless fluctuating relationship, which between tension and cooperation. Largely the tensions between the two countries centred on territorial disputes, strategic rivalry in the two World Wars, dispute over hydroelectric projects, and nuclear ambitions. ${ }^{18}$ Not long after the two nations gained independence, they were involved in a war against one another in the Cisplatine War. This war was induced by Brazil's annexation of the Cisplatine Province in 1821. Buenos Aires retaliated by rendering the Gauchos with matériels, which was a group of rulers who controlled the countryside of Montevideo just in 1825. ${ }^{19}$ The war emerged also as a consequence of Portugal-Spain rivalry that competed to dominate Latin America. Comparably, the Brazilian Army was much more powerful than Argentine's one. The battle between the two new states lasted for three years in which the war involved some different kind of battles. Amongst the battles were the Battle of Corales, the Battle of Colonia de Sacramento, the Battle of Los Pozos, the Battle of Quilmer, the Battle of Juncal, and the Battle of Ituzaigo. This war resulted an advantage for Uruguay which obtained its independence in 1828. The war ended as a result of Britain's intervention and Brazil's domestic problem which the people largely opposed the confrontation, since they viewed that war was solely a personal ambition of the emperor of Brazil. Conflicts that involved the two nations mainly motivated by irresolute border disputes which they inherited

\footnotetext{
${ }^{18}$ Christopher Topher Darnton. 2014. Rivalry and Alliance Politics in Cold War Latin America. Baltimore: John Hopkins University Press., 51

${ }^{19}$ Robert L. Scheina. 2003. Latin America's War 1791-1899. Vol. I. Washington, D.C.: Potomac Book., 167
} 
from Portugal and Spain. After the war, in the $19^{\text {th }}$ century Brazil and Argentina no longer had had any direct confrontation, rather the two states allied in several wars named the Platine War that occurred in 1864 up till 1870 against the insurgents and the Paraguayan War between the Triple Alliance facing the Paraguayan.

Yet, in the $20^{\text {th }}$ Century, distrustfulness was one amongst big obstacles of the rapprochement between the two governments as the Brazilian military officers and government officials stated that the Argentine was trying to insulate Brazil from the state of affairs in Latin America by collaborating with other Spanish speaking states in the region. ${ }^{20}$ Moreover, for the Brazilian elites, Argentina had a geopolitical aspiration in Latin America due its domination over Paraguay.

Before World War I, the military tension increased as a consequence of the Brazilian anxiety that the Argentine had an aggressive intention against it, for example Argentina issued an ultimatum regarding Brazil's naval build up which became a concern for Brazil. When the First World War commenced, Brazil took a stance with the Allies whereas Argentina favoured a neutral position. Argentina's decision aggravated its strained relationship with Brazil. Even in the inter-war period, there were some diplomatic clashes and arms races between the two states. ${ }^{21}$ The suspiciousness between the two neighbours mounted at its peak in 1930s when Argentina accused of complicity in the Chaco War.

In World War II Brazil reinstated its stance favouring the Allies, while Argentina remained neutral but tended to support the Axis. Such a stance caused anxiety again in the minds of Brazil's policy makers. Somehow, Brazilian leaders at the time believed that its apparent stance towards the Allies would have invited an invasion from Argentina or even the Nazi. In spite of that consideration, the Brazilian military perceived that Argentina along with other like-minded countries (neutral states) in South America would have insulated Brazil as well as blocked the influence of the United States in the region.

Following the end of World War II, Brazil and Argentina started to think about the improvement of bilateral relations after long period of hostility. In 1947, Juan Domingo Perón of Argentina encountered with Eurico Gaspar Dutra of Brazil. Even though the two states had had a variety of common interests such as anti-communist stance, nonetheless, the

\footnotetext{
${ }^{20}$ Stanley E. Hilton. 1985. "The Argentine Factor in Twentieth-Century Brazilian Foreign Policy Strategy." Political Science Quarterly 100 (1): 27-51., 31.

${ }^{21}$ Ibid, 29
} 
rapprochement could not be actualised due to domestic obstacles such as bureaucratic obstruction from state agencies like military and foreign ministries. The agencies had had several interest ranging from to maintain budget sharing, prestige, and autonomy. ${ }^{22}$ In spite of parochial perspective argument, other analyses argue that personality and international factors were crucial as well. There were some different views between the two presidents, for instance, some officials in the Dutra Administration somewhat detested President Perón, particularly, far-right politicians such as foreign ministers Joao Neves de Fontoura and his successor Raul Fernandes were hostile against Perón. Such a characteristic was demonstrated by the change of the Brazilian ambassador to Argentina Joao Baptista Lusardo with Cyro de Freitas Valle. ${ }^{23}$ Despite domestic factors, international factor had also been a consideration as some accounts argue, that US influence harmed the rapprochement between the two states, as some Brazil's politicians, who were proponents of the US while also somewhat disfavour Perón. Notwithstanding, as wrote by Darnton that the international factor, in particular the influence of the US on the failure of the rapprochement was not thoroughly significant. The US did construct amiable relationship with Brazil and Argentina, though in 1946 the US somehow declined to take part the Rio Conference hence the summit was adjourned, however, in 1947 the US advocated the Rio Conference as it commenced to re-establish its genial connection with Argentina. US conception of rebuilding cordial relationship, especially with Argentina was in order to anticipate communist resurgences in Latin America. At individual level despite the fact President Dutra disliked Peron, he agreed meeting President Peron while his predecessor President Vargas though had had common view with President Peron, nonetheless Vargas had not openly advocating the summit. Moreover, such officials in the Dutra Administration as foreign ministers Raul Fernandes (who was against Vargas) had similar view to Neves da Fontoura (had affinity with Vargas) in which they obstructed the summit. Ambassadors Lusardo. At the same time, despite ambassador Freitas Valle was an anti-Peron, nevertheless he was advocating the summit.

In 1950s concern over Argentina still determined Brazil's foreign policy. For instance, at the War College Brazilian officials and generals studied the probability of war against Argentina. Nevertheless, President Perón of Argentina suggested the formation of a tripartite customs union to Vargas in 1952. Then, President Vargas somewhat accepted the proposal,

\footnotetext{
${ }^{22}$ Christopher Topher Darnton. 2014. Rivalry and Alliance Politics in Cold War Latin America. Baltimore: John Hopkins University Press, 60.

${ }^{23}$ Ibid, 61.
} 
though his position was ambivalent regarding the proposal, considering domestic factor especially resistance from nationalist group and international factor which fear of its disengagement from the US. ${ }^{24}$

Then in the 1960s, the relationship between the two nations was relatively more stable. It was indicated, by Presidents Arturo Frondizi of Argentina and Janio Quadros of Brazil summit in 1961. The two leaders had several common views on democracy, economic development, and regional cooperation. From the summit, Frondizi and Quadros agreed on trade, cultural exchanges, and the Cuban revolution. However, after all. the summit invited opposition from militaries of both countries which was demonstrated by the occurrence of coup d'état. Henceforth, the summit failed to start the rapprochement between the two states. $^{25}$

In the 1970s, when a Peronist candidate, Hector Campora introduced a new way of the Argentinian foreign policy, again the Brazilian concern rose over its rivalry with Argentina. ${ }^{26}$ Notwithstanding, the two states endeavoured to restart rapprochement, with the summit between Presidents Lanusse of Argentina and Médici of Brazil. In spite of high expectations, the summit was unsuccessful to reach rapprochement. ${ }^{27}$ From parochial perspective, the summit failed because of obstacle came from foreign ministries and militaries.

However, the 1970s period marked the reestablishment of diplomatic relations between the two countries. According to Gardini, there are two dominant considerations why the enhancement of diplomatic relations occurred. First, reciprocal tolerance towards each dominance in regional affairs was terminated. Second, the situation in the international environment changed, especially considering the détente between the Soviet Union and the United States. ${ }^{28}$ Whereas there are three phases in the process of rapprochement. First, five efforts of regional integration. Second, the influences of international, regional, and national factors in regional integration process. Last, some important events which were crucial in determining regional integration.

\footnotetext{
${ }^{24}$ Gian Luca Gardini. 2010. The Origins of Mercosur. New York: Palgrave Macmillan, 21.

${ }^{25}$ Op.cit Darnton, 68-71.

${ }^{26}$ Hilton, Stanley E. 1985. "The Argentine Factor in Twentieth-Century Brazilian Foreign Policy Strategy." Political Science Quarterly 100 (1): 27-51., 34.

${ }^{27}$ Christopher Topher Darnton. 2014. Rivalry and Alliance Politics in Cold War Latin America. Baltimore: John Hopkins University Press, 80-81.

${ }^{28}$ Gian Luca Gardini. 2010. The Origins of Mercosur. New York: Palgrave Macmillan, 18.
} 
The event of the Plata Basin Treaty was one amongst crucial factors in the rapprochement between the two nations. Despite a treaty signing with Argentina, Brazil also signed some treaties regarding its rapprochement with other Spanish speaking countries, for example Brazil finalised a Treaty of Friendship and Cooperation with Venezuela and signed the Amazon Pact which was a multilateral framework for the Amazon states cooperation.

Argentina began to be more serious to consider relations improvement with Brazil after a military coup that toppled the Isabel Perón regime. Alas, there was yet an ambivalence in the Junta due to disagreement over the settlement of rivers disputes. But, Argentina then initiated the discussion of a Tripartite Commission in order to settle the Itaipú/Corpus matters. However, Brazil's government refused that initiative. ${ }^{29}$ Yet, the agreements did not make any progression for the relations of the two nations. But after all, Brazil, Argentina, along with Paraguay accorded to sign the Tripartite Agreement in 1979.

On the international context, the United States under the Carter Administration was considering to no longer advocate authoritarian regimes and implemented the policy of détente that included signing the non-proliferation treaty (NPT). The impact of the policies on the Brazil-Argentina relations is that the nuclear weapons which were favoured by the two states could not be pursued anymore. Thus, the nations agreed to terminate their nuclear programmes in 1980s. Another international event that contributed in stimulating the rapprochement was the international oil crisis of 1973-1974. The crisis affected Brazil's need for energy, it endeavoured to enhance its relationship with Argentina in order to obtain alternative sources of energy from the Plata basin. While at same time, Argentina had also some disputes with other neighbouring countries, especially with Chile which it obtained three strategic islands after the arbitration by the United Kingdom that were relatively beneficial for Chile. The decision exacerbated the tense relations between the two Spanish speaking states, even the two nations were prepared for direct war. This flawed relations completely compelled Argentina to reconsider its relations with Brazil in which already had shortcomings. Thus, it was somewhat unrealistic in the view of Argentina to have two adversaries. $^{30}$

In spite of international factors, internal factors such as ideological affinity was also crucial in determining the rapprochement. The two states were ruled by the juntas which

\footnotetext{
${ }^{29}$ Ibid, 27.

${ }^{30}$ Ibid, 31 .
} 
somehow intensified the relations between Brazil and Argentina. The juntas' administration in the two neighbouring states viewed that conflict should be forestalled which somewhat different from previous administrations.

The integration of the two states could only be actualised when they had converted themselves to democratic system. Argentina had become a democratic state after the military disengaged from politics whereas Brazil moved earlier towards democracy in 1979. The transition to democracy was stimulating an integration which was marked by the change of foreign policy way in both countries. Nevertheless, Argentina had conversed its foreign policy from hostile foreign policy to friendly foreign policy. While Brazil was still continuing its foreign policy principles.

Then, in 1984, the Argentine diplomat Dante Caputo visited Brazil. From this encountering, he analysed that there were some similar perspectives between Presidents Raúl Alfonsin of Argentina and Joao Figueiredo of Brazil. ${ }^{31}$ For illustration, they signed the Cartagena Consensus on foreign debt. Moreover, because Alfonsín's foreign policy emphasised the significance of Brazil, the improvement of diplomatic relations between the two nations became more profound. In January 1984, economic integration subject was commenced to be talked by Argentina's Secretary of External Relations Jorge Sábato and Secretary of Brazilian Foreign Affairs Itamaraty. Nevertheless, Brazil was still in the transitional step, thus somehow Itamaraty was unable to take more opening moves on integration. ${ }^{32}$ Three months later, both once again discussed on integration, from this meeting Itamaraty stated that the discussion was productive and he was optimistically the meeting would have advanced cooperation and integration between the two states.

In January 1985, President Figueiredo of Brazil took part in a meeting with Argentina's President Alfonsín. They discoursed about economic cooperation. Next month in 1985, the Brazilian elected president Tancredo Neves and President Alfonsín of Argentina met twice, in particular to consult about foreign debt. Moreover, the two leaders achieved a unanimity on the Contadora Group, nonpartisan international order, and general arms reduction. A closer cooperation between the two nations had become a reality when Alfonsín and elected President Brazil Sarney agreed to increase bilateral trade volume, specifically

\footnotetext{
${ }^{31}$ Ibid, 50.

${ }^{32}$ Ibid, 58.
} 
Brazil accepted Argentina's proposal to heighten its wheat export to Brazil. ${ }^{33}$ Next year, in July 1986, both presidents concorded signing the PICE (Integration and Economic Cooperation Programme). ${ }^{34}$ Nonetheless, since officials of both countries were apprehensive of the failure of PICE, in 1988, the two governments concorded on the Treaty of Integration, Cooperation, and Development. The Treaty was ratified by national parliaments of the two states and produced the initiation of free trade area. This treaty became a foundation of Mercosur.

The end of the Cold War, in conjunction with the promotion of globalisation, stimulated changes in relationship amongst South American states. Furthermore, the third wave of democratisation in Latin America including within four founding members, Uruguay, Paraguay, Brazil, and Argentina, crucially had boosted the process of integration between the four countries. ${ }^{35}$ Following civilian group took power in Uruguay's politics in 1984, the new government was considering to make closer cooperation with the two largest countries in the region, given its trade with Uruguay and Brazil contributed 37 per cent of its total international trade. In 1985, Brazil and Argentina consistently encouraged Uruguay to attend their summits. In 1989, after the democratisation of Paraguay, it began to be invited by the two countries. Brazil and Argentina contributed up to 35 per cent of all Paraguay's international trade.

In the following year, Brazil and Argentina had begun considering to expand their cooperation which with recruited new member states. Then, Uruguay, Argentina, Paraguay, and Brazil, ratified the Acta de Buenos Aires as the foundation of common market in the region. ${ }^{36}$ In October 1990, Argentina and Brazil finalised the Economic Complementation Agreement No. 14 (ACE), the agreement reemphasised the rest of previous arrangements and as an implementation of the Acta which was a political commitment of the four signatories. The four countries considered to advance all agreements. Paraguay proposed the blueprint of Common Market of the South which comprised the final aim of the association and its scheme to be able to expand its membership. Whereas, Argentina introduced the acronym "Mercosur". On March 26, 1991 the four states ratified the Treaty of Asunción. The treaty consisted of three principal pillars, first, the free movement goods and services, also the

\footnotetext{
${ }^{33}$ Ibid, 62.

${ }^{34}$ Ibid, 70.

${ }^{35}$ Huntington, Samuel. 1991. The Third Wave Democratization in the Late Twentieth Century. Norman: The University of Oklahoma Press especially p 22.

${ }^{36}$ Gian Luca Gardini, Op. cit., 93-94.
} 
elimination of all tariff and nontariff barriers. Second, the establishment of a common external tariff and a common trade policy towards third countries. Third, macroeconomic policies coordination. ${ }^{37}$

\section{Brazil, Mercosur, and Argentina}

As the largest state in South America, especially in Mercosur, there is certain impression that the relationship amongst Mercosur states is somewhat asymmetric. ${ }^{38}$ Statistically, Brazil is the fifth most populated country and its total area of about 8.5 million square $\mathrm{km}$. Brazil's GDP volume is thrice the combined GDP volumes of Argentina, Uruguay, and Paraguay. This imbalance invited negative perceptions from the other three members. Yet, in particular, Argentina seemed to be hesitant to deepen integration in Mercosur, especially on political integration. Political integration would have led to Brazil's subordination of Argentina. Therefore, particularly, substantive integration in Mercosur is rather difficult to be achieved. Even, there was a statement that Mercosur would not succeed. To forestall such a negative potential, since the Cardoso and Lula Administration, Brazil tried to make cooperative relations with Argentina, which their foreign policy focused on regional integration in Southern Cone. In spite of regional priority, Brazil, especially under Lula also had had an aspiration to expand its cooperation and influence outside the region, specially towards other south or developing countries.

President Cardoso as a pioneer of Brazil's active and open foreign policy, considered that Brazil should have controlled its own problem and future which actively contributed to the global order. ${ }^{39}$ Cardoso no longer exercised a distant foreign policy that centred on inactive foreign policy in the global stage. He began embracing rather more liberal foreign policy and dynamically emphasised institutionalist approaches. His foreign policy coincided with the end of the Cold War, that such low politics issues as economy, environmental protection, and human security had been as important as high politics. For the Cardoso Administration, Mercosur was an integral part of Brazil, since according to him, South

\footnotetext{
${ }^{37}$ Gardini, Gian Luca. 2010. The Origins of Mercosur. New York: Palgrave Macmillan, 96.

${ }^{38}$ Hernández, Lorena Granja. 2013. El Mercosur y sus asimetrías: análisis de la bilateralidad y sus condicionamientos políticos. Summary PhD Thesis, El Colegio de Jalisco.

39 Tullo Vigevani and Marcelo Fernandes de Oliveira. 2007. "Brazilian Foreign Policy in the Cardoso Era: The Search for Autonomy through Integration.” Latin American Perspective 34 (05): 58-80. doi:10.1177/0094582X07306164.58.
} 
America is geographically and historically inseparable from Brazil. ${ }^{40}$ There was a consideration that Mercosur would have been a basis for Brazil to extend its cooperation to the international level. Nevertheless, though Brazil attempted to build cooperative relations with the US, but Mercosur was used to balance US' endeavour to rebuild its influence in South America through the creation of Free Trade Area of the Americas (FTAA). Cardoso maintained, that FTAA was not suitable for Brazil. To challenge the creation of FTAA, President Cardoso had given particular treatment to Argentina, which Brazil was opening its market for Argentina that was based on preferential policy, this policy was under the framework of Mercosur. ${ }^{41}$ This policy though relatively influenced Argentina, however, Argentina was aware that it would have made Argentina overdependent on Brazil. Hence, President Menem of Argentina argued, that the FTAA and Mercosur must coexist. Despite this policy, Cardoso in consolidating and advancing Mercosur, and particularly towards Argentina, implemented several relevant policies. First, in his first term, Brazil initiated importing oil from Argentina, which in the past, largely imported oil from Gulf Countries such as Saudi Arabia and Iraq. Second, Argentina and Brazil unequivocally agreed to terminate all their nuclear weapon projects, unless if it for peaceful purpose. Third, Brazil built its own image as a peaceful and democratic country by mediating border conflicts between Ecuador and Peru. Also, Brazil attentively advocated reassurance of democracy in Paraguay and Venezuela, which the two states underwent institutional crisis. ${ }^{42}$

Following the ascendance of Luiz Inácio Lula da Silva as a president of Brazil, his foreign policy was characterised as a continuation of Cardoso's policy, but more focused on South-South cooperation. Regarding the FTAA negotiation, it seemed to President Lula that the FTAA was not really beneficial. Specifically, for Brazil, the FTAA did not meet Brazil's interests such as in terms of services, investment, agricultural subsidies. ${ }^{43}$ Therefore, he attempted to counterbalance US' effort to install the FTAA as a free trade framework in the Western Hemisphere. Despite the problem on technical aspects, Brazil also assessed that the FTAA is the prolongation of the Organisation of American States. Meanwhile, Argentina

\footnotetext{
40 Ibid, 68.

${ }^{41}$ Russell, Roberto, and Juan G. Tokatlian. 2016. "Contemporary Argentina and the Rise of Brazil.” Bulletin of Latin American Research 35 (1): 20-33., 21.

${ }^{42}$ Tullo Vigevani and Marcelo Fernandes de Oliveira Op.cit., 69.

43 Celso Amorum. 2010. "Brazilian Foreign Policy under President Lula (2003-2010): An Overview." Review of Brazilian Politics (53): 214-240., 217.
} 
under the Néstor Kirchner Administration was gradually disillusioned with the FTAA due to its disagreement over agricultural arrangement.

On Mercosur, the regional institution had been an integral part of Brazil's foreign policy under the Lula Administration. Mercosur was one of Lula's foreign policy priorities towards South America along with Brazil's focus on strategic cooperation with Argentina. In his foreign policy's plan, he stated that he would have reconstructed Mercosur through policy coordination and the formation of political and juridical institutions. To actualise its regional ambition, Brazil under the Lula Administration was trying to build a closer cooperation with Mercosur members for instance through its foreign direct investment, strategic partnerships, funding infrastructure project in South America. ${ }^{44}$ Even, before he was officially inaugurated as the president of Brazil, Lula was visiting Buenos Aires to discuss the matters of Mercosur. ${ }^{45}$

Even though the regional institution was established to create a common market for its members, however Brazil has been utilising Mercosur as a tool for its regional power's ambition and South America's integration project since the 2000s. It is demonstrated by following Argentina's financial crisis while Brazil's economy was relatively stable at that time. ${ }^{46}$ President Cardoso criticised the International Monetary Fund (IMF), which according to him, overly unresponsive to Argentina's financial crisis. In spite Brazil's criticism of the IMF, Brazil under the Cardoso Administration exhibited a solidarity with Argentina, during it experienced financial crisis while the US, the European Union (the EU), and private group (especially Wall Street) persistently criticised Argentina's policy of its financial crisis. ${ }^{47} \mathrm{Such}$ a solidarity, would have preserved the trust between the two countries. Via Mercosur, President Cardoso had provided more flexibilities to Argentina, such as Brazil's preferential policy, which it gave more receptive access to Argentina's exports.

During the Duhalde Administration, Argentina had been more receptive to Brazil. It occurred due to Argentina's domestic problems, especially the financial crisis. To solve such a problem, President Duhalde campaigned an advanced cooperation with Brazil and

\footnotetext{
${ }^{44}$ Susanne Gratius and Miriam Gomes Saraiva. 2013. Continental Regionalism: Brazil's prominent role in the Americas. Working Document, Brussels: CEPS, 6.

${ }^{45}$ Almeida Medeiros, Marcelo de, and Clarissa Franzoi Dri. 2013. "Which Brazilian Policy for Regionalism?

Discourse and Institutional development in Mercosur.” Estudios Internacionales 175: 41-61., 41.

${ }^{46}$ Susanne Gratius and Miriam Gomes Saraiva, Op. cit., 3-4.

${ }^{47}$ Tullo Vigevani and Marcelo Fernandes de Oliveira. 2007. "Brazilian Foreign Policy in the Cardoso Era: The Search for Autonomy through Integration." Latin American Perspective 34 (05): 58-80. doi:10.1177/0094582X07306164.23.
} 
encouraged Argentina to recognise its Latin American origin. Yet, there was a positive reception from the Duhalde Administration, as Brazil tried convincing Argentina that it was a reliable partner. For illustration, 57 percent of Argentina's leaders favoured Brazil as a they partner in South America, while 44 percent of the Argentinian people had positive view of Brazil. Meanwhile, Argentina's leaders had more positive perspective on Mercosur, which 90 per cent of them viewed the institution positively. Furthermore, 77 per cent of the Argentinian public perceived that Mercosur was crucial for Argentina. These positive views, invited an analysis that Argentina had acknowledge itself as a junior partner of Argentina. Even, there is argument that Argentina implicitly saw Brazil as a natural leader in South America. ${ }^{48}$ When Duhalde's successor Néston Kirchner assumed the office, positive views of Argentina relatively declined due to the Argentinians apprehension of the rising Brazil. Notwithstanding, initially, in his visit to Brazil, Kirchner praised Mercosur, which he argued that Mercosur was inseparable from the two nations. He also hoped a closer cooperation with Brazil, but he was critical of cooperation between the two nations, thus, Kirchner demanded more effective relations. Despite with all Kirchner's endeavours ${ }^{49}$ to balance Brazil's regional ambition, however, Brazil still had a significant contribution the Argentina's development, such as by ending Argentina's financial crisis via foreign direct investment (FDI). ${ }^{50}$ Cooperation with other potential powers also did not succeed, for instance, when Mexico became a member of the North American Free Trade Agreement (NAFTA), its interest towards South America gradually declined, also its dependence on US' market aggravated Mexico's disillusion with South America.

President Néston Kirchner's wife, Cristina Fernández de Kirchner succeeded him in Argentina's government. Her perspectives on Brazil were quite positive. During her presidency, 62 per cent of the Argentinian public favoured Argentina's membership in Mercosur, 14 per cent perceived the EU positively, and 7 per cent saw the FTAA was important for Argentina. In her administration, she shared view with Brazil, which, they were against any US' influence in the Southern Cone.

Theoretically, there are two factors why Brazil becomes a significant actor in the process of integration in South America and its leadership over Mercosur. First, defensive

\footnotetext{
${ }^{48} \mathrm{Ibid}, 23-24$.

${ }^{49}$ For example, such as by building cooperation with relevant potential powers, namely Venezuela, Chile, and Mexico

${ }^{50}$ Tullo Vigevani and Marcelo Fernandes de Oliveira Op. cit.,
} 
consideration, the three members of Mercosur realise that on the power aspect that they are relatively weaker than Brazil. Second, offensive factor which is Brazil comparably stronger than the other members. That is why, though Mercosur is a somewhat a regional ambition tool for Brazil, however because of those factors Mercosur is still preserved by its members. ${ }^{51}$ Moreover in reality, Brazil is the least dependent member on Mercosur due to its economic reforms during the Cardoso and Lula Administration. In spite of asymmetric relations within Mercosur, US and Mexico's disenchantment with South America, encouraged Brazil to succeed in subordinating Argentina. US' foreign policy which has been focused on the Middle-East and Asia-Pacific, gives Brazil more rooms and opportunity in achieving its regional ambition. Though, Brazil seems somewhat hesitant to be a regional power as a consequence of limited resources and domestic problems.

\section{Conclusion}

Argentina and Brazil had had long history of strategic rivalry since they gained independence. It occurred as a consequence of perception of each other, that each country wanted to be regional leader in South America. But, after the third wave of democratisation and rapprochement, then the integration between Brazil and Argentina, the two states along with other two founding members agreed to form Mercosur. The organisation aimed to make cooperation between its members closer, and to avoid any strategic rivalry such as in the Cold War. However, behind the creation of Mercosur, there is a regional leadership from Brazil which is comparably superior than the other members. In particular after the rise of Fernando Henrique Cardoso and Luis Inacio Lula da Silva as the presidents of Brazil, its foreign policy towards Mercosur had become a priority. The two presidents through the framework of Mercosur, had given Argentina particular access to its market, increased and intensified Brazil's involvement in Argentina's development project, and kept solidarity towards its neighbour when it underwent the financial crisis in 1998 up till 2002. As a consequence, there were positive views from public and leaders on Mercosur and Brazil. Despite, these positive views, during the Duhalde Administration of Argentina, he implicitly perceived that Argentina has been junior partner, whereas Brazil became a natural leader in the Southern

\footnotetext{
${ }^{51}$ Laura Gomez Mera. 2005. "Explaining Mercosur's Survival: Strategic Sources of Argentine-Brazilian Convergence.” Journal of Latin American Studies 37 (1): 109-140., P. 111.
} 
Cone. Nevertheless, Brazil's ambition is somehow difficult to be achieved, when there are still oppositions from its neighbours and its domestic problems still obstruct its own ambition.

\section{Bibliography}

2016. About Mercosur. Accessed October 24, 2018. http://en.mercopress.com/aboutmercosur.

Almeida Medeiros, Marcelo de, and Clarissa Franzoi Dri. 2013. "Which Brazilian Policy for Regionalism? Discourse and Institutional development in Mercosur." Estudios Internacionales 175: 41-61.

Amorum, Celso. 2010. "Brazilian Foreign Policy under President Lula (2003-2010): An Overview." Review of Brazilian Politics (53): 214-240.

Beeson, Mark. 2014. “American Hegemony and Regionalism: The Rise of East Asia and the End of the Asia-Pacific." Geopolitics 11 (4): 541-550. doi:10.1080/14650040600890727.

Binder, Leonard. 1958. "The Middle East as a Subordinate International System.” World Politics 10 (03): 408-429.

Dicken, Peter. 2015. Global Shift: Mapping the Changing Contours of the World Economy. 7th. New York: The Guilford Press.

Gardini, Gian Luca. 2010. The Origins of Mercosur. New York: Palgrave Macmillan.

Gratius, Susanne, and Miriam Gomes Saraiva. 2013. Continental Regionalism: Brazil's prominent role in the Americas. Working Document, Brussels: CEPS.

Hernández, Lorena Granja. 2013. El Mercosur y sus asimetrías: análisis de la bilateralidad y sus condicionamientos políticos. Summary $\mathrm{PhD}$ Thesis, El Colegio de Jalisco.

Hilton, Stanley E. 1985. "The Argentine Factor in Twentieth-Century Brazilian Foreign Policy Strategy." Political Science Quarterly 100 (1): 27-51. 
Huntington, Samuel. 1991. The Third Wave Democratization in the Late Twentieth Century. Norman: The University of Oklahoma Press .

Mcclelland, Charles A. 1996. Theory and the International System. New York: Macmillan.

Mera, Laura Gomez. 2005. "Explaining Mercosur's Survival: Strategic Sources of ArgentineBrazilian Convergence.” Journal of Latin American Studies 37 (1): 109-140.

Organski, A.F.K. 1968. World Politics. 2nd. New York: Random House.

Özdemir, Haluk. 2015. “An Inter-Subsytemic Approach in International Relations.” All Azimuth 4 (1): 5-26.

Russell, Roberto, and Juan G. Tokatlian. 2016. "Contemporary Argentina and the Rise of Brazil.” Bulletin of Latin American Research 35 (1): 20-33.

Scheina, Robert L. 2003. Latin America's War 1791-1899. Vol. I. Washington, D.C.: Potomac Book.

Snyder, Glenn H. 2002. "Mearsheimer's World-Offensive Realism and the Struggle for Security: A Review Essay.” International Security 27 (1): 149-173.

Thompson, William R. 1973. "The Regional Subsystem: A Conceptual Explication and a Propositional Inventory.” International Studies Quarterly 17 (1): 89-117.

Vigevani, Tullo , and Marcelo Fernandes de Oliveira. 2007. "Brazilian Foreign Policy in the Cardoso Era: The Search for Autonomy through Integration." Latin American Perspective 34 (05): 58-80. doi:10.1177/0094582X07306164.

Wu, Jennifer Pédussel. 2009. "Successful" Regionalism and the Role of Regional Hegemons. Working Paper, Berlin: Berlin School of Economics and Law. 